\title{
A short review on the potential of coffee husk gasification for sustainable energy in Uganda [version 1; peer review: 2
}

\section{approved]}

\author{
Gilbert John Miito (D), Noble Banadda
}

Department of Agricultural \& Bio-systems Engineering, Makerere University, Kampala, Uganda

V1 First published: 06 Oct 2017, 6:1809

https://doi.org/10.12688/f1000research.10969.1

Latest published: 06 Oct 2017, 6:1809

https://doi.org/10.12688/f1000research.10969.1

\section{Abstract}

Agricultural biomass is widely recognized as a clean and renewable energy source, with increasing potential to replace conventional fossil fuels in the energy market. Uganda, like other developing countries, has a high dependency (91\%) on wood fuel, leading to environmental degradation. With a coffee production of 233 Metric Tonnes per annum, relating to 46.6 Mega Tonnes of coffee husks from processing, transforming these husks into syngas through gasification can contribute to resolving the existing energy challenges. The objective of this article is to briefly review the energy potential of coffee husks through gasification, and how the gasification process could increase energy recoveries for coffee farmers. Previous findings indicate that the 46.6 Mega Tonnes per year of coffee husks generated in Uganda, with a heating value of $18.34 \mathrm{MJ} / \mathrm{kg}$, is capable of generating $24 \mathrm{GWh}$ of energy. This will address a $0.7 \%$ portion of the energy situation in Uganda, while protecting the environment.

\section{Keywords}

Agricultural Biomass, Coffee Husks, Gasification, Wood Fuel, Energy Recovery

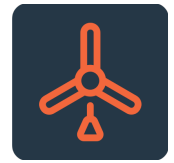

This article is included in the Energy gateway.

\section{Open Peer Review \\ Approval Status \\ 1 \\ 2 \\ version 1 \\ 06 Oct 2017
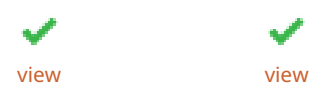

1. Jamidu H.Y. Katima, University of Dar es

Salaam, Dar es Salaam, Tanzania

2. Innocent Nhapi, Chinhoyi University of

Technology, Chinhoyi, Zimbabwe

Any reports and responses or comments on the article can be found at the end of the article. 
Corresponding author: Gilbert John Miito (miitogilbert@gmail.com)

Competing interests: No competing interests were disclosed.

Grant information: The author(s) declared that no grants were involved in supporting this work.

Copyright: $\odot 2017$ Miito GJ and Banadda N. This is an open access article distributed under the terms of the Creative Commons Attribution License, which permits unrestricted use, distribution, and reproduction in any medium, provided the original work is properly cited.

How to cite this article: Miito GJ and Banadda N. A short review on the potential of coffee husk gasification for sustainable energy

in Uganda [version 1; peer review: 2 approved] F1000Research 2017, 6:1809 https://doi.org/10.12688/f1000research.10969.1

First published: 06 Oct 2017, 6:1809 https://doi.org/10.12688/f1000research.10969.1 


\section{Introduction}

\section{Energy demand in an African context}

Energy demand is rising rapidly, mainly due to population increase and increasing industrial activities. This demand has led to an increase in prices of major energy sources, for instance fossil fuels ${ }^{1-4}$. Use of fossil fuels causes air pollution, which, over time, escalates climate change effects as emissions of greenhouse gases and other pollutants increases ${ }^{5-8}$. Due to the increase in energy demand and prices of fossil fuels, researchers are motivated to discover additional viable energy sources. A case of interest is Fernandes and Costa 9 , who noted that biomass, including wood agro residue, in Portugal has an annual energy potential of 160 Tera joules (TJ). In Mozambique, Vasco and $\operatorname{Costa}^{10}$ pointed out that agricultural biomass can cater for $32 \%$ of the country's energy demand.

Many sub-Saharan African (SSA) countries use agricultural biomass to cover most of their energy needs ${ }^{5}$, but the efficincies are low, and thus the raw material usage is high ${ }^{11}$. In Uganda, for example, woody biomass is used as wood fuel to provide for over 93\% of the country's energy needs ${ }^{12}$. This reliance on wood fuel significantly increases the rate at which the country's forest cover is shrinking, and is associated with the adverse change in weather patterns and consequent climate variability experienced in the country ${ }^{13}$. With Uganda's population growing at a rate of $3.2 \%$ per annum $^{14}$, the pressure on the country's forests is bound to increase if the country's dependence on wood fuel continues. On the other hand, alternative biomass sources, like agricultural and saw mill waste, and technologies, like pyrolysis and gasification, remain unexplored. Coffee, which is Uganda's top-earning export crop, is widely grown throughout the country, and yielded 233 mega tons (MT) in $2014^{15}$. During the processing of the coffee, a substantial bulk of coffee husks are generated. In total, 46.6 MT of coffee husks were generated from the $233 \mathrm{MT}$ of coffee produced, based on a 0.2 waste factor for coffee $^{16}$. These husks are currently being used as beddings in poultry units, farmers also use coffee husks to replenish nutrients in pineapple and banana gardens across the country and to a smaller extent for use in briquetting. However, the current uses amount to underutilization of the coffee husks in monetary and energy terms, and there is thus a need to improve coffee waste handling alternatives that encompass maximum utilization of the energy component of the waste, while also addressing the challenges associated with the use of woody biomass for energy reliance. This won't only address the energy crisis in the country, but also increase the economic value of the husks ${ }^{17}$.

Direct use of coffee husks as an energy source is hindered by the low efficiency of the energy recovery systems used. It is essential to transform the husks to a form that improves energy recovery. One process that can be considered is gasification, which involves alteration of compact carbonaceous fuel, in this case being the husks, into ignitable gas by partial incineration at elevated temperatures and moderate heating rates ${ }^{11,18}$. Through this process, coffee husks can be thermally converted to producer gas. Producer gas is a blend of carbon monoxide, hydrogen, methane, carbon dioxide and nitrogen. Producer gas is multipurpose in its use, as opposed to the solid biomass, from which it is derived ${ }^{19}$. This article reviews the potential for coffee husks, as an alternative to wood as feedstock, for gas fuel production through gasification in Uganda.

\section{The energy situation in Uganda \\ Electricity grid}

According to Karekezi and Kithyoma ${ }^{20}$, Africa is the least electrified continent in the world, and, in East Africa, Uganda is amongst the least electrified countries (Table 1). Uganda presently has one of the lowest electricity consumption per capita in the world at $215 \mathrm{kWh}$ per annum ${ }^{21}$. The typical value for SSA is $552 \mathrm{kWh}$ per capita, while that for the world is $2,975 \mathrm{kWh}$ per capita ${ }^{22}$. This low electricity coverage is attributed to electric tariffs and the fact that the electricity grid is concentrated in urban areas. Hence, people have continued to use wood fuel for their energy needs.

An examination of the power grid in East Africa indicates that the spread of electricity is mainly limited to main town areas, while rural regions have no access ${ }^{23}$ (Figure 1). In addition, some homesteads that are close to the network lines cannot afford electricity connections and user fees. Indeed access to electricity at a national level in Uganda is about $15 \%$, which is lower than other $\mathrm{SSA}^{24}$, with a rural coverage of $1 \%{ }^{5}$. As a result, many Ugandans depend on firewood and charcoal as their main energy source for lighting and cooking ${ }^{25-27}$. According to the Rural Electrification Agency, the total woody biomass consumption in Uganda in 2013 was 31.7 million tons. The total energy consumption per year in Uganda is approximately 45.1 million tonnes of wood, 1.2 million $\mathrm{m}^{3}$ of oil products, with a hydropower installed capacity of about $691.5 \mathrm{MW}$ and $100 \mathrm{MW}$ of thermal power ${ }^{28}$.

\section{Fossil fuel}

A small portion (7\%) of the energy demand in Uganda is met by fossil fuel ${ }^{29}$, which is primarily used for automobiles and generators, and, to a smaller extent, in form of natural gas. Although fossil fuels contribute a small portion of the energy demand, data shows that there is increase in the volume of petroleum products imported into the country. In 2013, there was an increase of 4.6 and $4.3 \%$ in the import volume of kerosene and diesel, respectively (Figure 2) ${ }^{15}$. This increment implies an increased reliance on an energy source that is unsustainable. From Figure 2, it is also observable that there was a greater increase in the amounts of kerosene imported compared with other energy sources. This is highly attributed to the higher demand for kerosene, which the majority of the rural population uses for lighting ${ }^{30}$.
Table 1. Electrification patterns and Energy
consumption in East African countries ${ }^{31}$.

\begin{tabular}{|l|c|c|}
\hline Country & $\begin{array}{c}\text { Energy consumption } \\
\text { (\% households) }\end{array}$ & $\begin{array}{c}\text { Electrification } \\
\text { (\% households) }\end{array}$ \\
\hline Biomass & Other \\
\hline Kenya & 70 & 30 \\
\hline Rwanda & 90 & 10 \\
\hline Tanzania & 90 & 10 \\
\hline Uganda & 93 & 7 \\
\hline
\end{tabular}




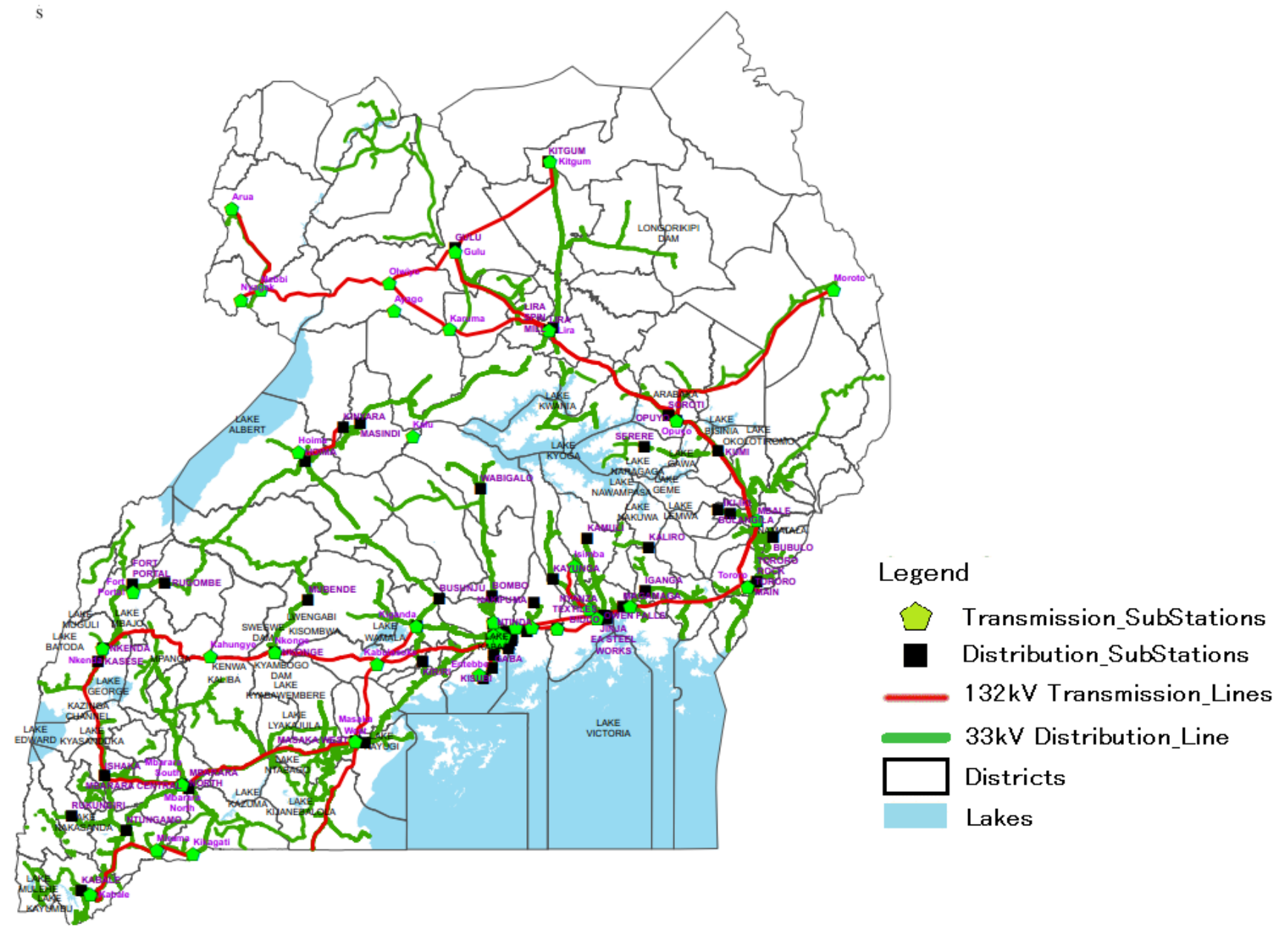

Figure 1. Uganda electric grid and sub stations. Adapted from 32.

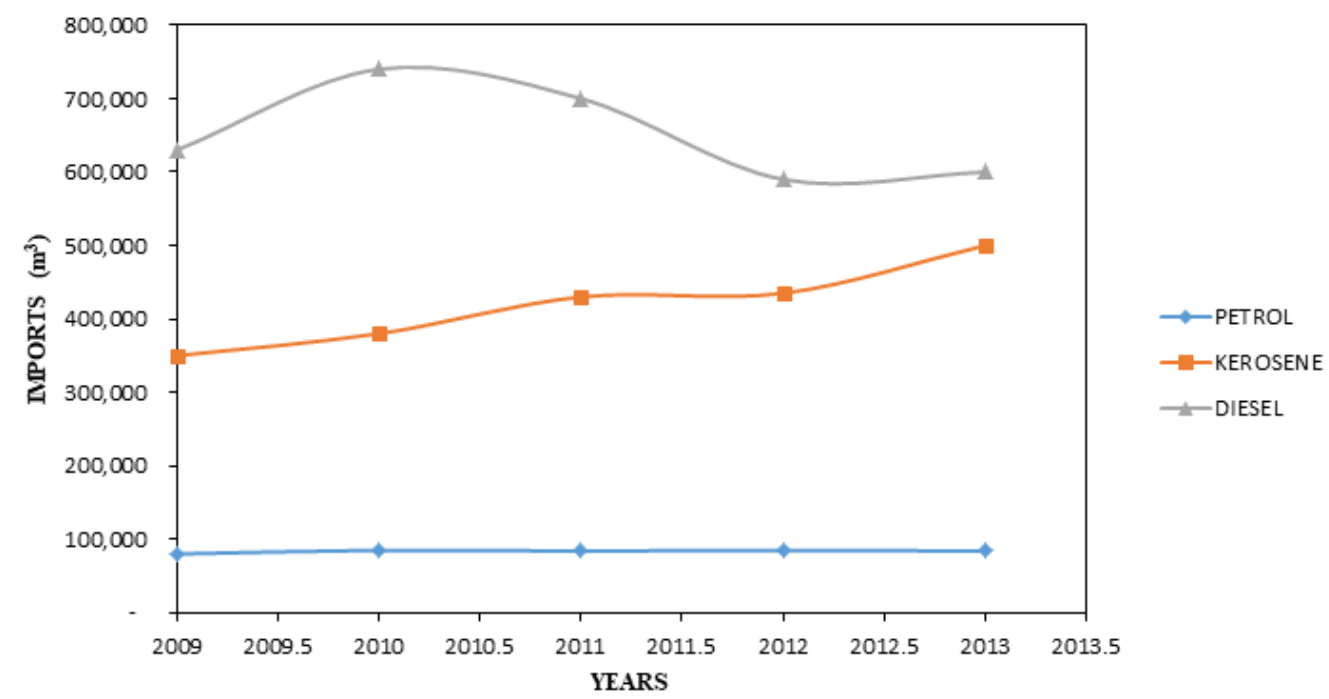

Figure 2. Petroleum product importation in Uganda ${ }^{15}$. 


\section{Biomass energy}

Uganda is an energy deprived nation with restricted access to electricity and heavy dependence on wood fuel to cater for the energy requirements. There has been a general increase in the wood consumption for fuel in the country (Figure 3$)^{33}$. This heavy consumption of wood fuel has contributed to high rates of deforestation, further leading to unreliable rainfall and rampant soil erosion $^{34}$.

Charcoal is largely used in metropolitan areas, whereas firewood, agricultural biomass and wood chippings are commonly utilized in rural areas ${ }^{35}$. The sugar industry is the sole industry in Uganda that exploits agricultural biomass in the form of bagasse for cogeneration, but the technology should be adopted even for energy production in homesteads.

\section{Renewable energy}

The promotion of renewable energy has been recognized as a potential method of addressing power shortages in the East African region ${ }^{20}$. The renewable energy policy of Uganda states that the increasing cost of fossil-based fuels makes them costly for developing countries, and fossil fuels have an unreliable future. Uganda has extensive renewable energy resources for production of energy and the delivery of energy services, such as biomass, geothermal, large scale hydro, hydro, wind and solar energy, yet these remain un-tapped, primarily due to the apparent technical and financial incapacitations. With the exclusion of biomass, whose energy contribution is significant, the other sources contribute $\sim 5 \%$ of the country's total energy consumption. This hinders the scope and productivity of economic activities that can be undertaken in any part of the country. Biomass is an extremely available resource, and agricultural waste, such as coffee husks, is a large quota of the biomass yield. Therefore, it is advisable that the use of these readily abundant resources should be increased.

\section{Status of gasification in Uganda}

Gasification technology is not extensively used nor known in Uganda $^{11}$, but in Kenya, a neighboring country of Uganda, gasification of sawmill dust has been implemented with a power output of $76 \mathrm{GWh}^{36}$. Although previous investigations showed that smallscale wood gasifiers could be economically and socially feasible energy systems to generate electricity in rural areas ${ }^{37}$, it is not a widely implemented technology in SSA. Obua et al. ${ }^{38}$ noted that gasification is not widely applied in Uganda and reported only two established gasification units: one at Muziizi Tea Estate for electricity generation using wood feedstock and the other at Paramount Cheese Diaries for industrial heat production, which uses papyrus reeds. The gasification unit at Muziizi Tea Estate was stated to be $87 \mathrm{~kW}$ average power output, although rated at $200 \mathrm{~kW}^{39}$, indicating a low operating efficiency. Buckholz et al. ${ }^{37}$ described the economics of a $10 \mathrm{~kW}$ wood gasification unit in Mukono, Uganda, and concluded that the technology is proven, efficient and economically viable. The existing gasification units in Uganda rely on firewood, which is a factor in deforestation, and yet the literature supports use of coffee husks. Previous studies in Sweden ${ }^{40}$ and Portugal ${ }^{41,42}$ have reported successful gasification of coffee husks for various applications, including fuel, electrical generation and soil conditioning, but the possibility of the technologies in less developed countries is still abstract.

\section{Deforestation situation}

Uganda has an expanse of 241,550.7 square kilometers, including water bodies. Forests are one of the chief land uses although there has been a significant decline in forest area over the past two decades $^{5,43}$. Between 1990 and 2010 total forest cover dropped from 24 to $12.7 \%$ of the total land area, implying an average decline of close to $2 \%$ per year (Figure 4$)^{28}$. Although agriculture is the major cause of deforestation, wood extraction for energy production, which has been steadily rising over the years, has been noted as one of the

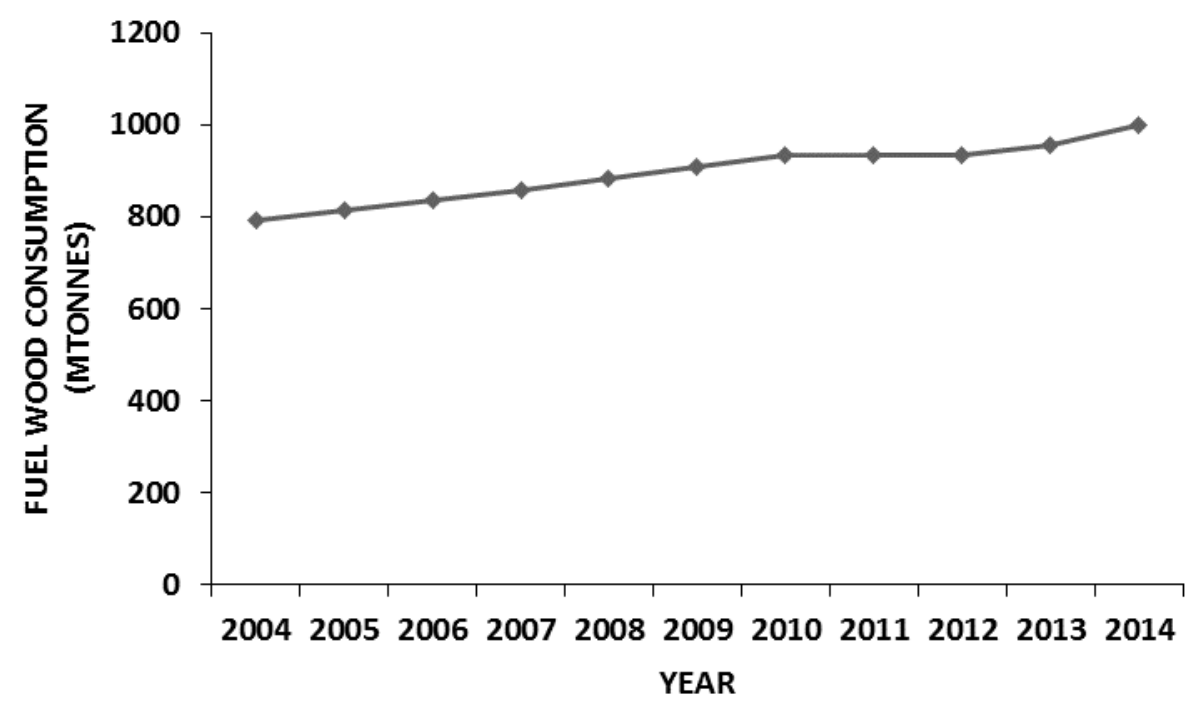

Figure 3. Trend of fuel wood consumption in Uganda ${ }^{33}$. 
direct reasons for deforestation ${ }^{38}$. The forest area reduction contributes to environmental hazards and unreliable rainfall manifested in the country. Currently, approximately 90,000 ha of forest and vegetation are destroyed yearly, leading to fuel wood shortage in rural areas and increasing prices of charcoal and fuel wood ${ }^{15}$.

\section{Coffee production in Uganda}

Uganda is ranked second to Ethiopia in regards to coffee production in Africa ${ }^{44}$, and there is a current government intervention of coffee replanting, which is bound to boost coffee production in Uganda ${ }^{45}$. Uganda produces two types of coffee: Robusta coffee and Arabica coffee (also termed as Mountain coffee). Over the years, Robusta coffee has been produced in larger quantities and accounts for $80 \%$ of production compared with Arabica coffee. In 2013, Uganda produced a sum of 232,561 tons of coffee (Figure 5) from a producing area of about 310,000 hectares, of which $75 \%$ was Robusta ${ }^{15}$. Currently, the (Figure 5 and Figure 6$)^{15}$.
The major coffee growing regions include the Western Highlands, Bugisu around Mt. Elgon and areas around Lake Victoria basin (Figure 7). According to Lora and Andrade ${ }^{16}$, coffee has a waste factor of 0.2 by weight, and as such this yields a coffee husk production of approximately 46.6 MT per year ${ }^{46}$. These husks are used as soil conditioners, briquetting, poultry bedding, and some are burnt as biomass energy sources, but with low efficiency. Significant to note is that the production surpasses the use of the husks ${ }^{24}$.

\section{Gasification potential of coffee husks}

According to Acharya et ll $^{47}$, processing of coffee yields about $22 \%$ of its weight as coffee husk. The annual generation of coffee husks in Uganda is estimated to be $46.6 \mathrm{M}$ tons per annum, rising from $172 \mathrm{M}$ tons per annum reported in $2004^{48}$. According to $\mathrm{Mhilu}^{40}$, coffee has an energy value of $18.34 \mathrm{MJ} / \mathrm{kg}$. At a maximum this would harness efficiencies of $855 \mathrm{TJ}$ with $46.6 \mathrm{M}$ tons

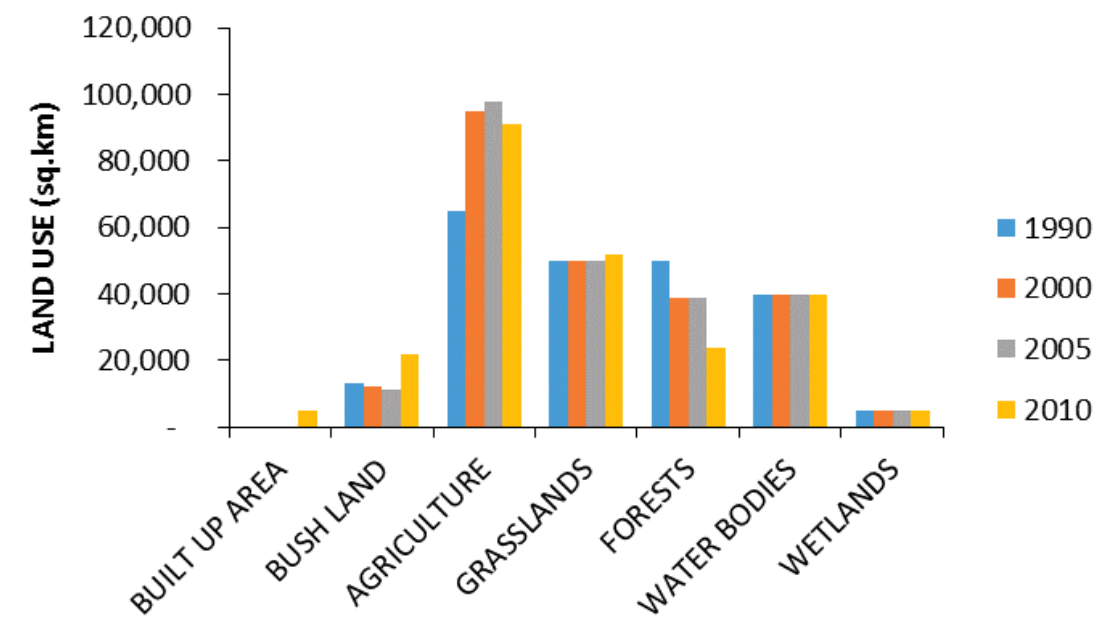

Figure 4. Area for land cover by type for the years $1990-2010^{15}$.

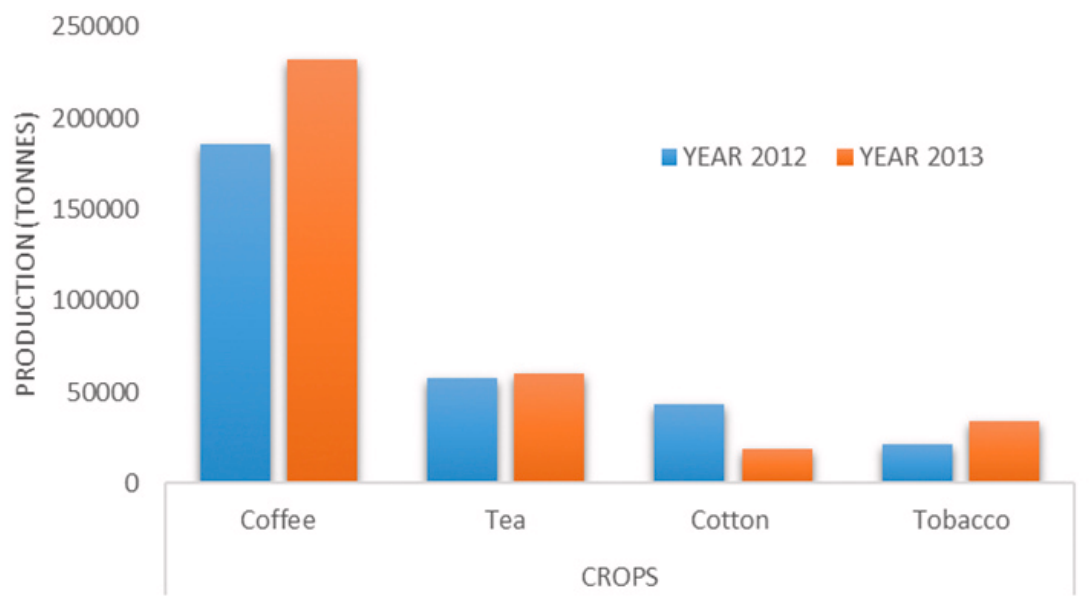

Figure 5. Cash crop production of Uganda ${ }^{15}$. 


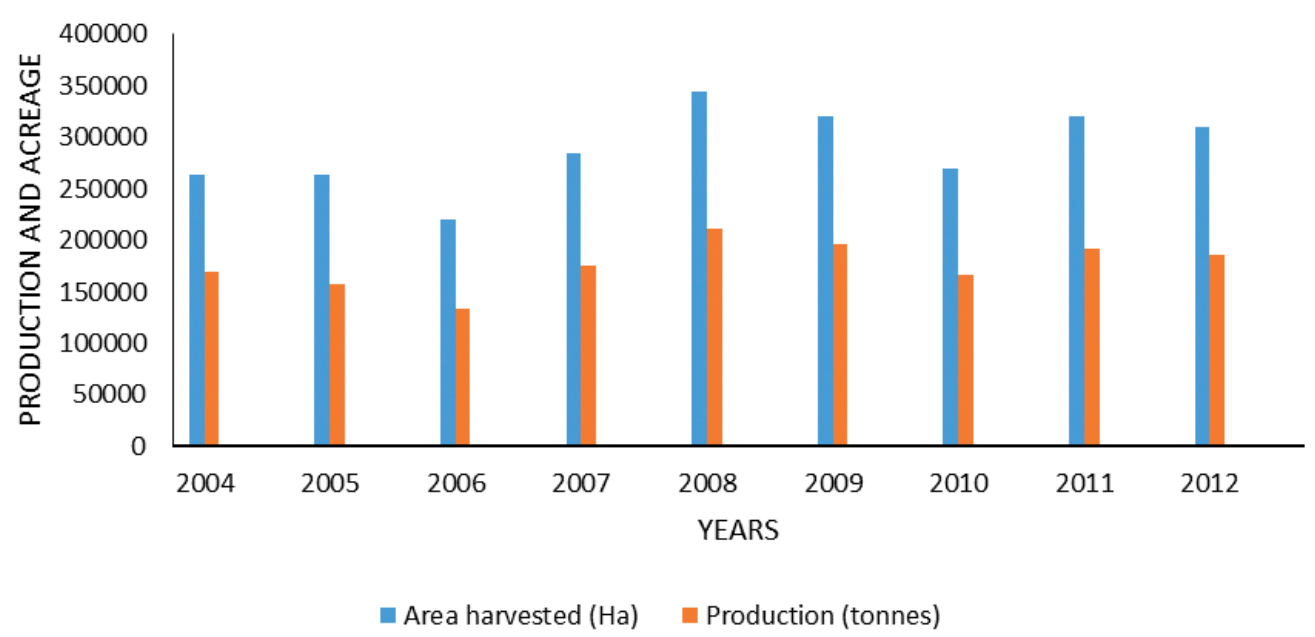

Figure 6. Coffee production in Uganda ${ }^{33}$.

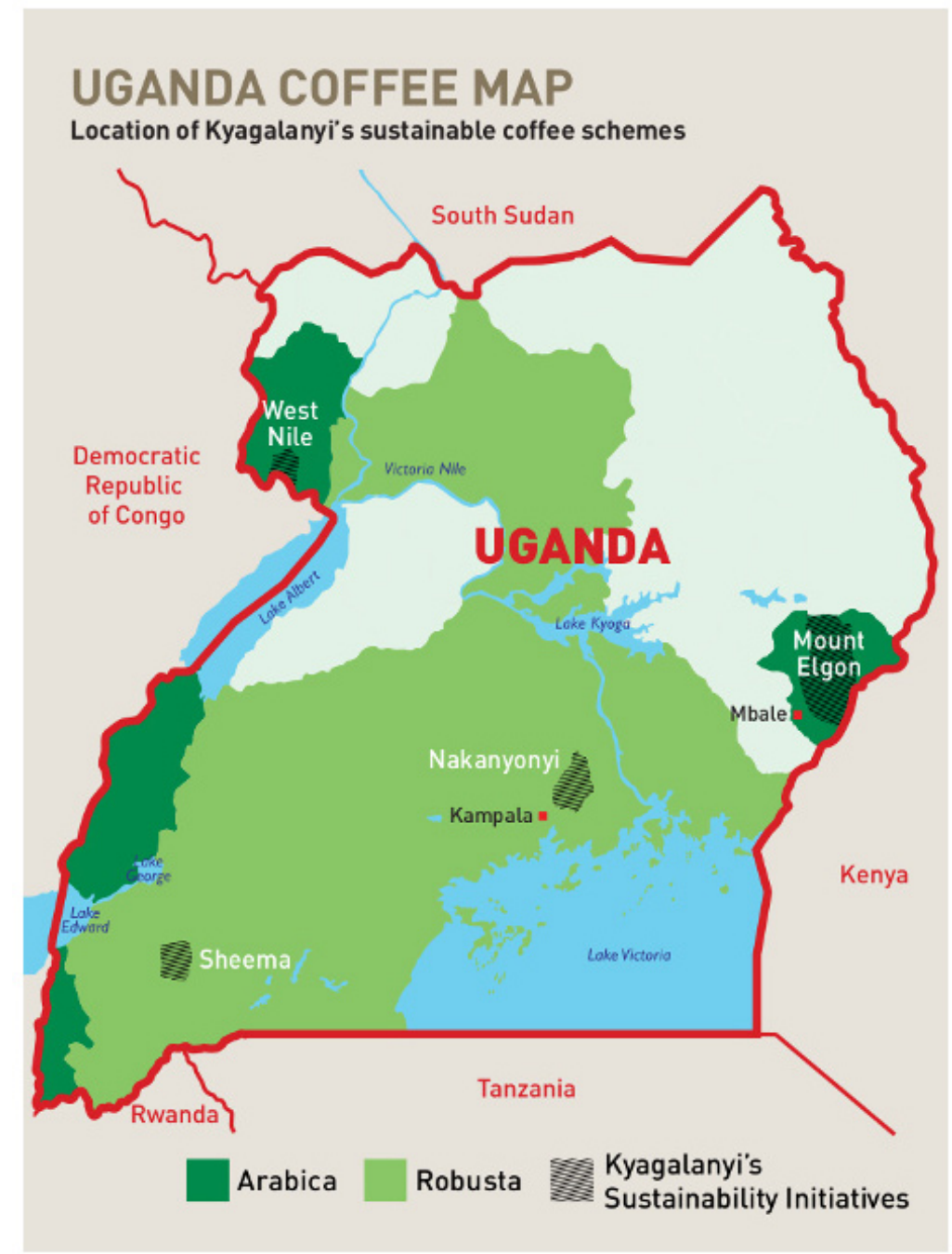

Figure 7. Coffee growing areas. Permission to use this figure was granted by Kyagalanyi Coffee Ltd (http://kyagalanyi.co.ug/sustainability/ sustainable-coffee-schemes/). 
of coffee husks. At a conversion efficiency of $65 \%$, the generated coffee husks have a potential of $24 \mathrm{GWh}$ energy production. This would translate to better efficiencies and environmental protection, yet reducing the reliance on wood fuel.

A study was carried out by Pereira et $a l .{ }^{49}$ concerning the development of gasification stoves. They found that the gasification process yields emissions to the environment, but the amounts are small compared with fossil fuels and direct ignition of the biomass. Through gasification, the coffee husks can be put to an environmentally sound use, as the emissions associated with open burning are reduced ${ }^{50}$. The technology has been shown to be viable for a variety of feedstock, including waste from paper mills, mixed plastics, forest industry waste and agricultural residues ${ }^{28}$. The coffee husk gasification technology has the potential to better livelihoods and contribute to local progress by providing electricity access to societies in rural $\mathrm{Uganda}^{30}$.

\section{Conclusions}

This short review critically focusses on the fact that gasification of coffee husks can address a portion the energy demand problem in Uganda, while enhancing cleaner production. The review of the literature shows that coffee husks have the potential for conversion to clean gas fuels for energy generation on an industrial scale through gasification. If the renewable energy policy of Uganda emphasizes the adoption of highly efficient renewable technologies, the heavy reliance of wood for fuel will be curbed. The Government of Uganda should effectively implement the coffee replanting scheme. This will increase the coffee yield, which in turn will increase the amounts of coffee husks produced. These coffee husks, if properly harnessed, can be a clean energy alternative. Uganda has a massive potential to produce energy from coffee husks, as coffee is a major cash crop from the country. If utilized in a viable manner, coffee husks could contribute to $24 \mathrm{GWh}$ of energy, while decreasing deforestation and environmental degradation in the country, which are associated with the current energy sources. The technology adoption will further improve the livelihood of the residents, as well as lessen the pressure on wood fuel. However, the possibility of sustainable energy derivation from coffee husks is attached to the increasing production of coffee by allocating more unutilized land to coffee growing and also growing of improved and high yielding coffee varieties. Nevertheless, emphasis should be also put on food crops to avoid food insecurity.

\section{Author contributions}

Both authors made substantial contributions to conception and design, and acquisition of data, and analysis and interpretation of data. They also participated in drafting the article and revising it. The second author also gave final approval of the version submitted.

\section{Competing interests}

No competing interests were disclosed.

\section{Grant information}

The author(s) declared that no grants were involved in supporting this work.
1. Wolfram C, Shelef O, Gertler P: How will energy demand develop in the developing world? J Econ Perspect. 2012; 26(1): 119-138. Publisher Full Text

2. Omer AM: Energy, environment and sustainable development. Renew Sustainable Energy Rev. 2008; 12(9): 2265-2300. Publisher Full Text

3. Asif M, Muneer T: Energy supply, its demand and security issues for developed and emerging economies. Renew Sustainable Energy Rev. 2007; 11(7): 13881413.

Publisher Full Text

4. Demirbaş A: Biomass resource facilities and biomass conversion processing for fuels and chemicals. Energy Convers Manag. 2001; 42(11): 1357-1378. Publisher Full Text

5. Zanchi G, Frieden D, Pucker J, et al.: Climate benefits from alternative energy uses of biomass plantations in Uganda. Biomass Bioenergy. 2013; 59: 128-136. Publisher Full Text

6. Dincer I: Renewable energy and sustainable development: a crucial review. Renew Sustainable Energy Rev. 2000; 4(2): 157-175. Publisher Full Text

7. Paul S, Bhattacharya RN: $\mathrm{CO}_{2}$ emission from energy use in India: a decomposition analysis. Energy Policy. 2004; 32(5): 585-593. Publisher Full Text

8. Swart R, Amann M, Raes F, et al:: A good climate for clean air: linkages between climate change and air pollution. An editorial essay. Clim Change. 2004; 66(3): 263-269. Publisher Full Text

9. Fernandes $\mathrm{U}$, Costa $\mathrm{M}$ : Potential of biomass residues for energy production and utilization in a region of Portugal. Biomass Bioenergy. 2010; 34(5): 661-666. Publisher Full Text

10. Vasco H, Costa M: Quantification and use of forest biomass residues in Maputo province, Mozambique. Biomass Bioenergy. 2009; 33(9): 1221-1228. Publisher Full Text

11. Okello C, Pindozzi S, Faugno S, et al:: Development of bioenergy technologies in Uganda: A review of progress. Renew Sust Energ Rev. 2013; 18: 55-63. Publisher Full Text

12. Bingh LP: Opportunities for utilizing waste biomass for energy in Uganda. Master's Thesis. 2004: Institutt for energi- og prosessteknikk. Reference Source

13. Haines A, Kovats RS, Campbell-Lendrum D, et al:: Climate change and human health: impacts, vulnerability and public health. Public Health. 2006; 120(7): 585-596. PubMed Abstract | Publisher Full Text

14. Okello C, Pindozzi S, Faugno S, et al:: Bioenergy potential of agricultural and forest residues in Uganda. BioMass BioEnerg. 2013; 56: 515-525. Publisher Full Text

15. UBOS: Statistical Abstract. Uganda Bureau of Statistics: Uganda, 2015. Reference Source

16. Lora ES, Andrade RV: Biomass as energy source in Brazil. Renew Sust Energ Rev. 2009; 13(4): 777-788. Publisher Full Text

17. Abbasi T, Abbasi SA: Biomass energy and the environmental impacts associated with its production and utilization. Renew Sust Energ Rev. 2010; 14(3): 919-937. Publisher Full Text 
18. Deal C, Brewerb CE, Brownb RC, et al.: Comparison of kiln-derived and gasifierderived biochars as soil amendments in the humid tropics. Biomass Bioenergy. 2012; 37: 161-168.

Publisher Full Tex

19. Sheth PN, Babu BV: Experimental Studies on Downdraft Biomass Gasifier. 2012; 031: 2-7. Reference Source

20. Karekezi S, Kithyoma W: Renewable energy strategies for rural Africa: is a PV-led renewable energy strategy the right approach for providing modern energy to the rural poor of sub-Saharan Africa? Energy Policy. 2002; 30(11-12): 1071-1086.

Publisher Full Text

21. PWC: Uganda's FY 2013/14 Post Budget Analysis. 2013 Reference Source

22. OIU: Uganda: The Risks and Benefits of Going Nuclear. 2015 [cited 2016 15-APRIL]. Reference Source

23. Diechmann $\mathrm{U}$, Craig M, Siobhan M, et al:: The economics of renewable energy expansion in rural sub-saharan Africa. Energy Policy. 2011; 39(1): 215-227.

Publisher Full Text

24. Ferguson $\mathrm{H}$ : Briquette businesses in Uganda. The potential for briquette enterprises to address the sustainability of the Ugandan biomass fuel market. 2012.

Reference Source

25. Kaijuka E: GIS and rural electricity planning in Uganda. J Clean Prod. 2007; 15(2): 203-217. Publisher Full Text

26. Katimbo A, Kiggundu N, Kizito S, et al.: Potential of densification of mango waste and effect of binders on produced briquettes. Agric Eng Int. 2014; 16(4): $146-155$.

Reference Source

27. Kayanja F, Byarugaba D: Disappearing forests of Uganda: The way forward. Curr Sci. 2001; 81(8): 936-947. Reference Source

28. Belgiorno V, De Feo G, Della Rocca C, et al.: Energy from gasification of solid wastes. Waste Manag. 2003; 23(1): 1-15. PubMed Abstract | Publisher Full Text

29. Yevich R, Logan AJ: An assessment of biofuel use and burning of agricultural waste in the developing world. Global Biogeochem Cycles. 2003; 17(4). Publisher Full Text

30. Buchholz T, Da Silva I: Potential of distributed wood-based biopower systems serving basic electricity needs in rural Uganda. Energy Sustain Dev. 2010; 14(1): 56-61. Publisher Full Text

31. Komakech AJ, Banadda NE, Gebresenbet G, et al:: Maps of animal urban agriculture in Kampala City. Agron Sustain Dev. 2014; 34(2): 493-500. Publisher Full Text

32. ERA: Transmission Grid Development Plan. Uganda. 2014 Reference Source

33. FAO: Statistical Yearbook 2014. Asia and the Pacific food and agriculture. 2014 Reference Source

34. Mani S, Tabil LG, Sokhansanj S: Effects of compressive force, particle size and moisture content on mechanical properties of biomass pellets from grasses. Biomass Bioenergy. 2006; 30(7): 648-654 Publisher Full Text

35. Khundi F, Jagger P, Shively G, et al.: Income, poverty and charcoal production in Uganda. For Policy Econ. 2011; 13(3): 199-205. Publisher Full Text

36. Senelwa K, Sims RE: Opportunities for small scale biomass-electricity systems in Kenya. Biomass Bioenergy. 1999; 17(3): 239-255. Publisher Full Text

37. Buchholz $\mathrm{T}$, Volk $\mathrm{T}$, Tennigkeit $\mathrm{T}$, et al.: Economics of a gasification based minigrid--a case study from a $10 \mathrm{~kW}$ unit in Uganda. Proceedings of the Industrial and Commercial Use of Energy Conference. South Africa. Reference Source

38. Obua J, Agea JG, Ogwal JJ: Status of forests in Uganda. Afr J Ecol. 2010; 48(4): 853-859.

Publisher Full Text

39. Mangoyana RB, Smith TF: Decentralised bioenergy systems: A review of opportunities and threats. Energy Policy. 2011; 39(3):

1286-1295.

Publisher Full Text

40. Mhilu CF: Modeling of Coffee Husks Degradation Process under High Temperature Gasification (HTAG) Regime. Open Journal of Renewable Energy and Sustainable Development. 2014; 1(1): 1-13. Publisher Full Text

41. Menéndez JA, Domínguez A, Fernández Y, et al.: Evidence of self-gasification during the microwave-induced pyrolysis of coffee hulls. Energ Fuel. 2007 21(1): 373-378 Publisher Full Text

42. Couto N, Silva V, Monteiro E, et al.: Experimental and numerical analysis of coffee husks biomass gasification in a fluidized bed reactor. Energy Procedia. 2013; 36: 591-595. Publisher Full Text

43. Omeja PA, Chapman CA, Obuaa $J$ et al: Intensive tree planting facilitates tropical forest biodiversity and biomass accumulation in Kibale National Park, Uganda. Forest Ecol Manag. 2011; 261(3): 703-709. Publisher Full Text

44. Hammond S: Uganda Coffee Annual Uganda Coffee Annual Report. 2012. Reference Source

45. Benin S, You L: Benefit-Cost Analysis of Uganda's Clonal Coffee Replanting Program, An Ex-Ante Analysis. Intl Food Policy Res Inst. 2007; 744. Reference Source

46. Yin XL, Wu CZ, Zheng SP, et al:: Design and operation of a CFB gasification and power generation system for rice husk. Biomass Bioenergy. 2002; 23(3): 181-187.

Publisher Full Text

47. Acharya B, Dutta A, Basu P: An investigation into steam gasification of biomass for hydrogen enriched gas production in presence of $\mathrm{CaO}$. Int $\mathrm{J}$ Hydrogen Energ. 2010; 35(4): 1582-1589. Publisher Full Text

48. Wang $\mathrm{J}, \mathrm{Hu} \mathrm{Z}, \mathrm{Xu} \mathrm{X}$, et al.: Emissions of ammonia and greenhouse gases during combined pre-composting and vermicomposting of duck manure. Waste Manag. 2014; 34(8): 1546-1552. PubMed Abstract | Publisher Full Text

49. Pereira EG, da Silva JN, de Oliveira JL, et al:: Sustainable energy: A review of gasification technologies. Renewable and Sustainable Energy Reviews. 2012; 16: 4753-4762.

Publisher Full Text

50. Han J, Mol AP, Lu Y, et al.: Small-scale bioenergy projects in rural China: essons to be learnt. Energy Policy. 2008; 36(6): 2154-2162.

Publisher Full Text 


\section{Open Peer Review}

\section{Current Peer Review Status:}

\section{Version 1}

Reviewer Report 04 December 2017

https://doi.org/10.5256/f1000research.11824.r26767

(C) 2017 Nhapi I. This is an open access peer review report distributed under the terms of the Creative Commons Attribution License, which permits unrestricted use, distribution, and reproduction in any medium, provided the original work is properly cited.

\section{Innocent Nhapi}

Department of Environmental Engineering, Chinhoyi University of Technology, Chinhoyi, Zimbabwe

Thank you for giving me this opportunity to review this article. The review is well written and focused and gives a good overview of the subject and possibility of utilising coffee husk gasification for sustainable energy in Uganda. I only made a few notable observations which are outlined below:

There are some sections with bold and factual statements which needs to be backed by literature. An example is on page 2, paragraph 2, where uses of rice husks in Uganda are discussed. Another example is this sentence from page 4: With the exclusion of biomass, whose energy contribution is significant, the other sources contribute $\sim 5 \%$ of the country's total energy consumption. Some factual statements are referenced but the authors can go on and find some statistics on coverage - an example is page 4, second paragraph.

This sentence on page 5 is not complete: Currently, the (Figure 5 and Figure 6) ${ }^{\mathbf{1 5}}$

Make this sentence more clearer in meaning: The annual generation of coffee husks in Uganda is estimated to be $46.6 \mathrm{M}$ tons per annum, rising from $172 \mathrm{M}$ tons per annum reported in 2004 - what is rising here?

The energy needs to be solved are distributed around Uganda and so also is the cultivation of coffee. The authors need to consider the logistical and economic implications of their proposal and recommend how the gasification plants and energy produced will be distributed for the benefit of the rural peasants who are currently using firewood as source of fuel.

Is the topic of the review discussed comprehensively in the context of the current literature?

Yes 
Are all factual statements correct and adequately supported by citations? Partly

Is the review written in accessible language?

Yes

Are the conclusions drawn appropriate in the context of the current research literature? Yes

Competing Interests: No competing interests were disclosed.

I confirm that I have read this submission and believe that I have an appropriate level of expertise to confirm that it is of an acceptable scientific standard.

Reviewer Report 02 November 2017

https://doi.org/10.5256/f1000research.11824.r27378

(C) 2017 Katima J. This is an open access peer review report distributed under the terms of the Creative Commons Attribution License, which permits unrestricted use, distribution, and reproduction in any medium, provided the original work is properly cited.

Jamidu H.Y. Katima

Department of Chemical and Mining Engineering, University of Dar es Salaam, Dar es Salaam, Tanzania

The review is relevant considering the current energy situation i.e. dwindling of fossil fuel resources and the impact of the same to climate change. Use of sustainable renewable resource which are considered to be carbon neutral is very important.

However, the current generation of coffee husks (only meeting $0.7 \%$ of energy demand) does not provide comfort for sustainable energy supply. Although the paper discusses the intention of Uganda to increase acreage of coffee plantation, it does not discuss to what extent this will be done to meet even $20 \%$ of Uganda's energy supply.

Specific Comments

Abstract

1. Line 4, the Authors are stating that Uganda is producing 233 Metric Tonnes of coffee, which produce 46.6 Mega Tonnes. These numbers do not make sense. Unless 233 are in Mega Tonnes

2. Line 5, insert "per year" between "husks" and "from"

3. Line $13,0.7 \%$ of total energy from coffee husks do not tally with the use of "sustainable energy" - probably instead the Authors should use contribute to energy mix

Introduction

1. Line 5, the Authors imply other pollutants contribute to greenhouse gases, they should be 
specific by mentioning which ones, otherwise they should change the statement

2. Second paragraph, second line, last word "efficiencies" is misspelled

The Energy Situation in Uganda

Fossil Fuels

1. Line 3, the Authors are making reference to use of Natural Gas. My understanding is that Uganda is not using NG, probably they wanted to mean "Liquefied Petroleum Gas (LPG)"

Biomass Energy on page 4

1. Second paragraph, line 5, Authors should change "Should" to "could"

Status of gasification in Uganda

1. Line 21 " replace the word "electrical" with "electricity"

\section{Gasification potential of coffee husks (page 5)}

1. Line 2 the Authors states that the coffee yield $22 \%$ of its weight as coffee husks. When you consider that Uganda produces 233 Mega Tonnes, then the coffee husks do not compute to 46.6 Mega Tonnes

2. The statement" The annual generation of coffee husks in Uganda is estimated to be 46.6 $M$ tons per annum, rising from $172 \mathrm{M}$ tons per annum reported in 2004" does not seem correct. 172 Mega Tonnes is larger than 46.6 Mega Tonnes

Conclusion

1. Line 8, use of statement "the heavy reliance of wood for fuel will be curbed" is a heavy statement without qualification particularly when you consider that the coffee husks contribute only $0.7 \%$ of energy in Uganda

2. Line 12, insert the word "source" between "a" and "clean"

Is the topic of the review discussed comprehensively in the context of the current literature?

Yes

Are all factual statements correct and adequately supported by citations? Yes

Is the review written in accessible language?

Yes

Are the conclusions drawn appropriate in the context of the current research literature? Partly

Competing Interests: No competing interests were disclosed.

Reviewer Expertise: Renewable energy

I confirm that I have read this submission and believe that I have an appropriate level of expertise to confirm that it is of an acceptable scientific standard. 
The benefits of publishing with F1000Research:

- Your article is published within days, with no editorial bias

- You can publish traditional articles, null/negative results, case reports, data notes and more

- The peer review process is transparent and collaborative

- Your article is indexed in PubMed after passing peer review

- Dedicated customer support at every stage

For pre-submission enquiries, contact research@f1000.com 